\title{
THE EFFECT OF DRIP IRRIGATION, PHOSPHOGYPSUM AND VARIOUS DOSES AND FORMS OF MINERAL FERTILIZERS ON CHEMICAL, PHYSICAL AND PHYSICO-CHEMICAL PROPERTIES OF DARK CHESTNUT SOIL
}

\section{Shkoda O. A.}

\section{INTRODUCTION}

The water reclamation of lands is one of the main factors of intensification of agriculture in the areas with insufficient and unstable humidification. At the same time, irrigation is one of the most active factors of anthropogenic pressure on environment in general and, in particular, on the meliorated land.

The practice of the use of drip irrigation in the conditions of the South of Ukraine has shown that its use without considering regional peculiarities and quality of irrigation water can lead to negative changes in soil processes and regimes and, first of all, to the manifestation of the secondary alkalination and salinization of soils $s^{1,2,3}$.

In this regard, it is necessary to scientifically substantiate patterns and nature of changes in soil properties, their indices of fertility and ecological state in specific conditions of local humidification, development of measures for prevention of degradation of agro-meliorative state of lands at dripirrigation with waters of low quality (mineralized water with unfavorable ratio of mono- and divalent cations). Solving these issues is a relevant scientific direction, which promotes preservation of ecological and agro-melìorative soil conditions and obtaining sustainable levels in yields of crops.

The study was carried out at the research field of the Institute of Irrigated Agriculture of NAAS in the short-field experiment, placed in the zone of action of the Ingulets irrigation system. Field study scheme was as follows: 1) without irrigation, fertilizers and ameliorant - control 1; 2) irrigation, without fertilizers and ameliorant - control 2; 3) irrigation $+\mathrm{N}_{120} \mathrm{P}_{90}$ (recommended fertilizer dose); 4) irrigation+calculated dose of fertilizers (nitrogen fertilizer - ammonium nitrate); 5) irrigation+calculated dose of fertilizers (nitrogen fertilizer - calcium nitrate); 6) irrigation+phosphogypsum

\footnotetext{
1 Землі Інгулецької зрошувальної системи: стан та ефективне використання. За наук. ред. В.О. Ушкаренко, Р.А. Вожегової. К.: Аграрна наука, 2010. 352 с.

${ }^{2}$ Кукоба П.І., Балюк С.А., Ладных В.Я. Повышение плодородия мелиоративного фонда. Почвы Украины и повышение их плодородия, т. 2. К.: Урожай, 1988. С. 92-103.

${ }^{3}$ Рабочев И.С. Использование минерализованных вод для орошения и рассоления почв, основное направления дальнейших исследований. М.: Колос, 1973. С. 6-25.
} 
3.0 t/ha (under pre-sowing cultivation); 7) irrigation+phosphogypsum 1.9 t/ha (in the sowing strip); 8) irrigation+calculated dose of fertilizers (nitrogen fertilizer - calcium nitrate)+phosphogypsum 1.9 t/ha (in the sowing strip); 9) irrigation with improved water (calcination)+calculated dose of fertilizers (nitrogen fertilizer - ammonium nitrate). The crop - annual green onion, variety Khaltsedon. The technology is generally accepted for the Steppe zone of Ukraine, excepting the studied factors. In the experiment we used a strip sowing scheme $7+20+7+20+7+20+7+52$.

\section{Ion-salt composition of soil solution of dark chestnut at drip irrigation with applications of phosphogypsum and mineral fertilizers}

It is known that irrigation engages into production process such important components of biosphere as soil, moisture and plants that are closely interconnected by streams of water, energy, substance and information. The practice of irrigation of dark chestnut soils with mineralized waters in the zone of unstable humidification confirms the ability to obtain high and stable crop yields. At the same time, there is a number of negative effects of irrigation, affecting soil fertility, agro-melìorative conditions and, in particular, the salt regime ${ }^{4}$.

Soil solution is the most dynamic and active component of soil. The composition of soil solution is formed at the expense of intra-soil processes - biological, chemical, biochemical, that closely depend on environmental conditions, including adjacent phases of the soil (solid, gaseous), with which the liquid phase is in a dynamic hydrological equilibrium ${ }^{5}$.

The studies found that drip irrigation with slightly mineralized water led to accumulation of soluble salts, mainly in the soil layer 0-30 $\mathrm{cm}$ (Table 1).

The salt content at the end of the vegetation of the crop increased not only in the area of humidification (sowing strip), but also in the nonirrigated spacing (between the strips). So, in the variant without fertilizer and meliorant, the amount of salts increased on the average for three years of the study in the strip by 0.0382 , and between the strips -0.014 percent points in comparison with the control without irrigation. The increase of salts content in the soil occurred due to the anions of chloride and sulphate and magnesium and sodium cations. In this case, their number in the sowing strip (humidifying) increased by $0.39 ; 0.25$ and $0.14 ; 0.44 \mathrm{meq} / 100 \mathrm{~g}$, and between the strips (large inter-row spacing) - by 0.16 ; 0.08 ; 0.10 and 0.14 meq/100 g of soil, respectively.

\footnotetext{
${ }^{4}$ Остапов В.И., Сафонова Е.П. Влияние орошения на плодородие почв степной зоны Украины. Гидротехника и мелиоращия, № 5. 1986. С. 54-57.

${ }^{5}$ Дорогунцов С.I., Муховиков А.М. Оптимізація природокористування. Природні ресурси: еколого-економічна оцінка. К.: Кондор, 2004. Т. 1. 291 с.
} 
$\frac{0}{0}$

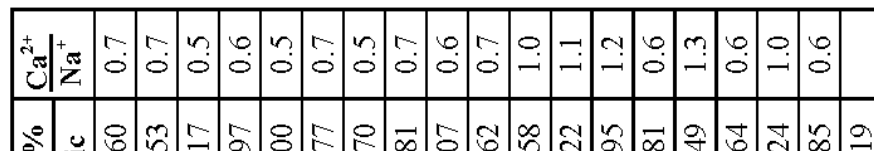

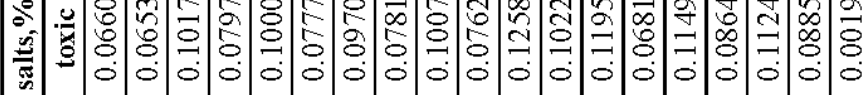

(5) 4 क्ष

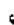

ד.

클

$\bar{a}$

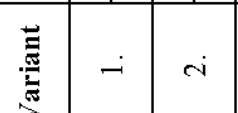




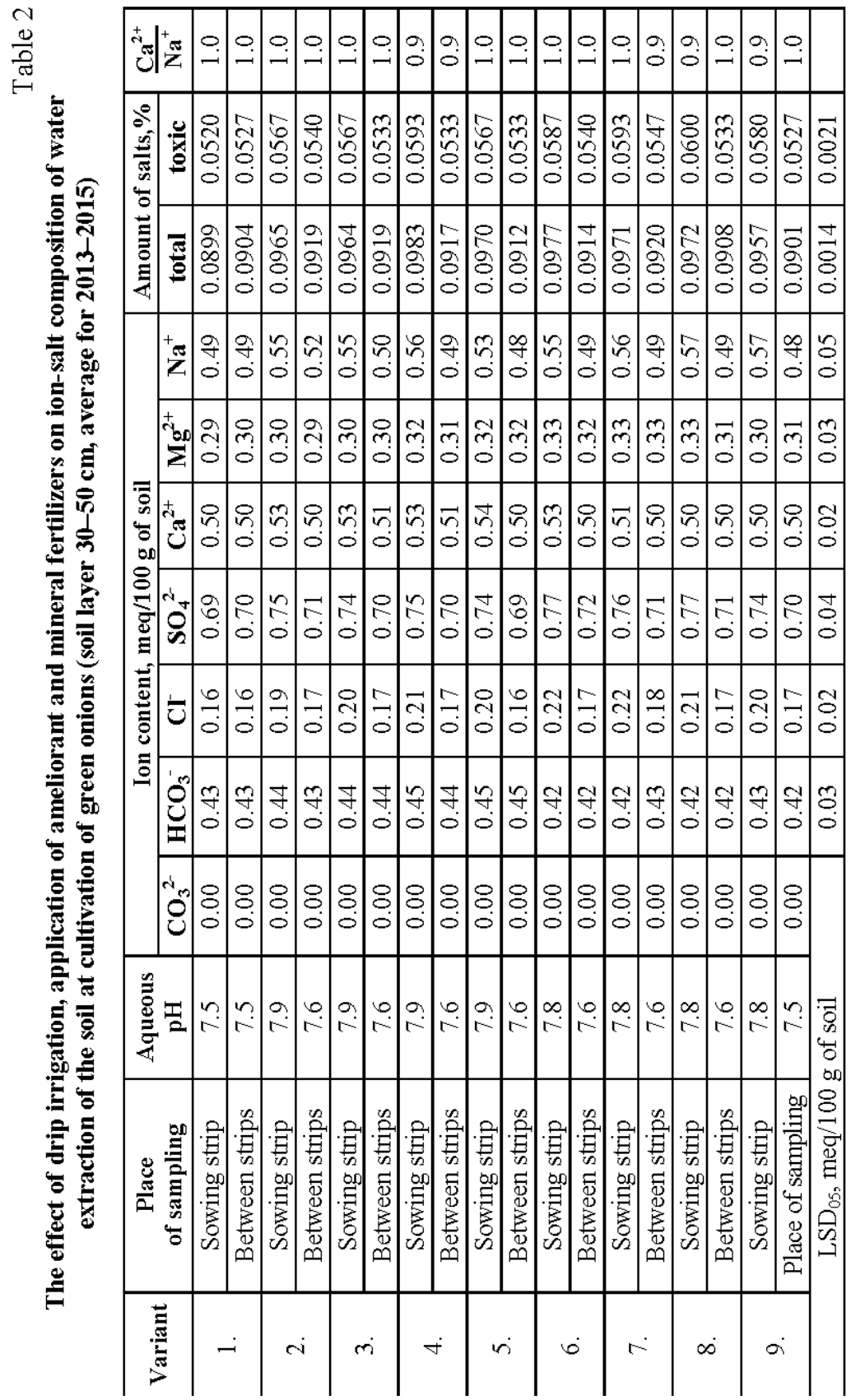


等

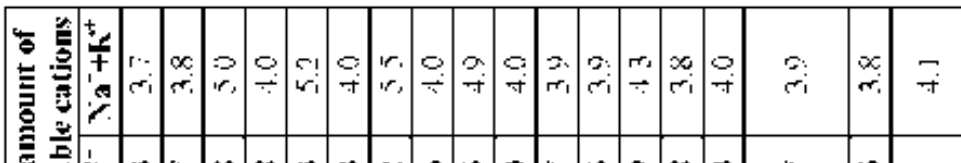

흘

\#

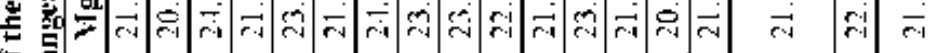

5

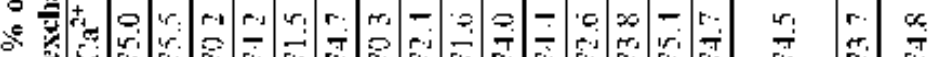

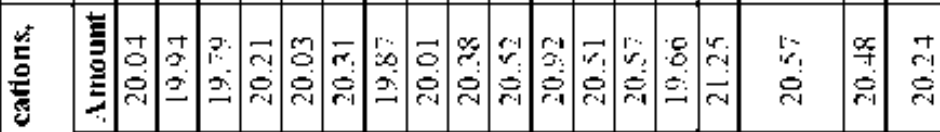

穿!

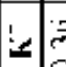

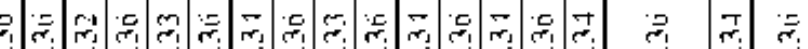

要

군

an

s

는

$=+\infty$ क

00

000

要

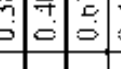

$=\overrightarrow{0}$

$+\frac{1}{2} \because$

ㅂ.

音

흘 항

혼

F

푼

ह

焉

0

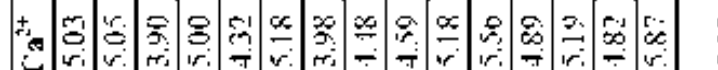

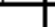

를

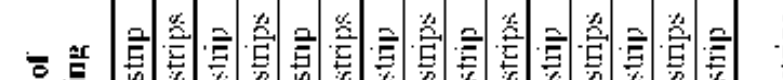

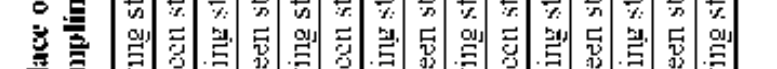

돌

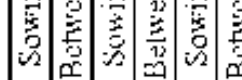

\begin{tabular}{l|l|l|l|l|l} 
& & & & & \\
\hline & &
\end{tabular}

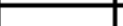


The increase in sodium content in the soil solution was the cause of reduction in the ratio of calcium to sodium by 0.2 units, indicating an increase in the intensity of development of soil salinity. The study of ion-salt composition of the water extraction of the sub-arable layer of the soil $(30-50 \mathrm{~cm})$ showed that drip irrigation somewhat increased the content of water-soluble salts only in the humidification zone (Table 2). Thus, their number in the control at irrigation increased by $0.0066 \%$, and in the variants with application of mineral fertilizers and ameliorant - by $0.0053-0.0079 \%$ compared with the variant without irrigation. The increase in salt content was due to the toxic salts of chloride and sulphate of sodium.

Application of mineral fertilizers $\mathrm{N}_{120} \mathrm{P}_{90}$ and calculated dose of fertilizers (nitrogen in the form of ammonium, calcium nitrate) has not significantly changed the qualitative composition of exchangeable cations in the soil absorbtion complex, both in the sowing strip and between strips, compared to the irrigated control. However, it should be noted that application of the calculated dose of fertilizers (nitrogen fertilizer - ammonium nitrate) in the soil of sowing strip there was a tendency to form the highest number of the absorbed sodium - $0.75 \mathrm{meq} / 100 \mathrm{~g}$, which by $0.5 \%$ exceeds the sum of exchangeable cations in the variant with the application of calcium nitrate.

The use of phosphogypsum both in pre-sowing application in the dose $3.0 \mathrm{t} / \mathrm{ha}$ and in the sowing strip in $1.9 \mathrm{t} / \mathrm{ha}$ had a positive effect on the qualitative composition of the absorbed bases in comparison with the irrigated control. The content of absorbed calcium in the soil in the zone of humidification increased by 1.29-1.66 meq/100 g, and the number of exchangeable magnesium and sodium decreased by $0.35-0.39$ and $0.14-0.20 \mathrm{meq} / 100 \mathrm{~g}$, respectively. The soil after gypsum application belonged to non-saline by the content of exchangeable sodium (2.3-2.6\% of the sum of cations).

Combined use of phosphogypsum and calcium nitrate did not contribute to further improvement of qualitative composition of the soil, i.e., reduction of the amount of exchangeable sodium in the soil of sowing strip of green onions. It remained at the level of $2.4 \%$ of the sum of cations.

Irrigation with the water of improved quality (after calcination) by the effect on the qualitative composition of the absorbed bases in the soil of the zone of humidification was not inferior to the phosphogypsum fed sowing strip and it was compatible to the use of calcium nitrate. Quantitative indices of exchangeable cations of SAC were approaching the values of the control variant without irrigation.

It should be noted that, according to the total indicator of monovalent cations $\left(\mathrm{Na}^{+}+\mathrm{K}^{+}\right)$, the soil in all the variants of the experiment was classified by the degree of secondary salinity as slightly saline. 


\section{Agrophysical properties of the soil in the conditions of drip irrigation at the cultivation of green onion}

Agrophysical degradation is one of the most common phenomena on irrigated lands. Under the influence of irrigation, agrophysical properties of soils (black, chestnut) undergo significant changes manifested in the destructure of an arable layer, the increase of clodding and the reduction of the agronomically valuable units' content; reduction of porosity, water permeability and compaction of the profile ${ }^{6}$.

The greatest value amonh the agrophysical properties belongs to the bulk density and structural composition. These indicators depend mainly on the granulometric and mineralogical composition of the soil and the content of humus in them. However, the intensity and direction of changes in the soil processes depends on the quality of irrigation water, the regime of irrigation and agricultural machinery used in the cultivation of crops.

One of the important dynamic characteristics of the physical properties of soil is its structure. It is characterized by such values as bulk density and porosity.

The analysis of the data obtained in our researches regarding the bulk density of the soil showed that it was $1.35 \mathrm{~g} / \mathrm{cm}^{3}$ in the control variant without irrigation, and in the variants with the application of mineral fertilizers and phosphogypsum it was $1.35-1.38 \mathrm{~g} / \mathrm{cm}^{3}$.

Therefore, there is no significant difference in the above-mentioned variants. However, a detailed analysis of our research findings showed that the coefficient of variation in the soil bulk density indicators on the variants with irrigation increased in 2.1-4.7 times compared with the control without irrigation, pointing out to a significant imbalance in this indicator in the dripirrigated conditions.

For the soils of homogeneous granulometric composition the total porosity of the soil is a function of the bulk density. Therefore, the total porosity of the soil layer was also independent on the factors that we have studied. It was almost identical - 46.9-48.1\%. The coefficient of variation of the total porosity of the soil in the variants with irrigation was also 2.2-3.7 times higher than in the control without irrigation.

It is known that soil has the ability to form aggregates of different sizes, shapes and durability from mechanical elements. The formation of aggregates is a complex physico-chemical process determined by the action of forces of different nature (capillary, gravity, adhesion, coagulation, etc.).

In the studies, dry sifting of the layer of dark chestnut soil 0-30 cm found out that at the end of vegetation of the plants (technical maturity

${ }^{6}$ Ромащенко М.І. Зрошення земель в Україні. Стан та шляхи поліпшення. К.: «Світанок», 2000. 114 с. 
of green onion) drip irrigation in the variant without the use of mineral fertilizers and phosphogypsum led to an increase of soil clodding. The content of aggregates larger than $10 \mathrm{~mm}$ in the variant increased by $23.42 \%$ compared with a control option without irrigation (Table 4). The increase in this fraction was mainly due to the little fractions of the size of $0.25-1.00 \mathrm{~mm}$ and microaggregates (less than $0.25 \mathrm{~mm}$ ). There was a decrease in the number of agronomically valuable aggregates by $16.61 \%$ and the most agronomically valuable aggregates of the size $1-5 \mathrm{~mm}$ - by $9.82 \%$.

It was determined that quantitative changes of the aggregate state of the soil under the influence of drip irrigation with slightly mineralized waters of the second class resulted in the decrease of its structural coefficient twice compared with the non-irrigated analogue.

The determination of water resistance aggregates (wet sifting) testified, that the amount of the aggregates with dimensions of more than $0.25 \mathrm{~mm}$ in the control variant without irrigation was $36.56 \%$, and under the influence of irrigation on the variant with no fertilizers and phosphogypsum it decreased by $3.99 \%$. Particularly noticeable changes in the water-resistant structure of the irrigated soil were observed in the amount of agronomically valuable aggregates of size $0.25-1.00 \mathrm{~mm}$ and the most agronomically valuable (1-3 mm) fractions. Thus, in the conditions of irrigation, the content of agronomic aggregates had a tendency to increase (by 1.84\%), which was explained (as noted above), by the formation of dense waterproof (almost without pores) aggregates. At the same time, the most agronomically valuable components of the arable layer of the irrigated soil decreased by 1.9 times. In the determination of the coefficient of water resistance for dry and wet sifting, we found that in the conditions of irrigation, this figure also had a tendency to decrease.

The evaluation of agrophysical state found that at drip irrigation, the degree of degradation of the bulk density of the arable layer $(0-30 \mathrm{~cm})$ remains, as in the non-irrigated soil and, at the level of the slight, and by the content of air-dry aggregates with dimensions $0.25-10 \mathrm{~mm}$ and waterproof aggregates of more than $0.25 \mathrm{~mm}$ - passes from slight to moderate degree of degradation.

So, it was determined that application of mineral fertilizers $\left(\mathrm{N}_{120} \mathrm{P}_{90}\right.$, calculated doses of fertilizers (nitrogen fertilizer - ammonium and calcium nitrate) did not substantially affect the aggregate composition of 0-30 cm layer of the irrigated soil (in the area of the sowing strip) comparatively to the control with irrigation. In this case, the parameters of the main indices of the macrostructure of the soil were close: the content of aggregates with dimensions of more than $0.25-1.00 \mathrm{~mm}-7.92-8.37 \%$ and $0.25-10 \mathrm{~mm}-$ $54.39-54.95 \%$, the sum of water-resistant aggregates larger than $0.25 \mathrm{~mm}-$ 30.20-32.04\%. 


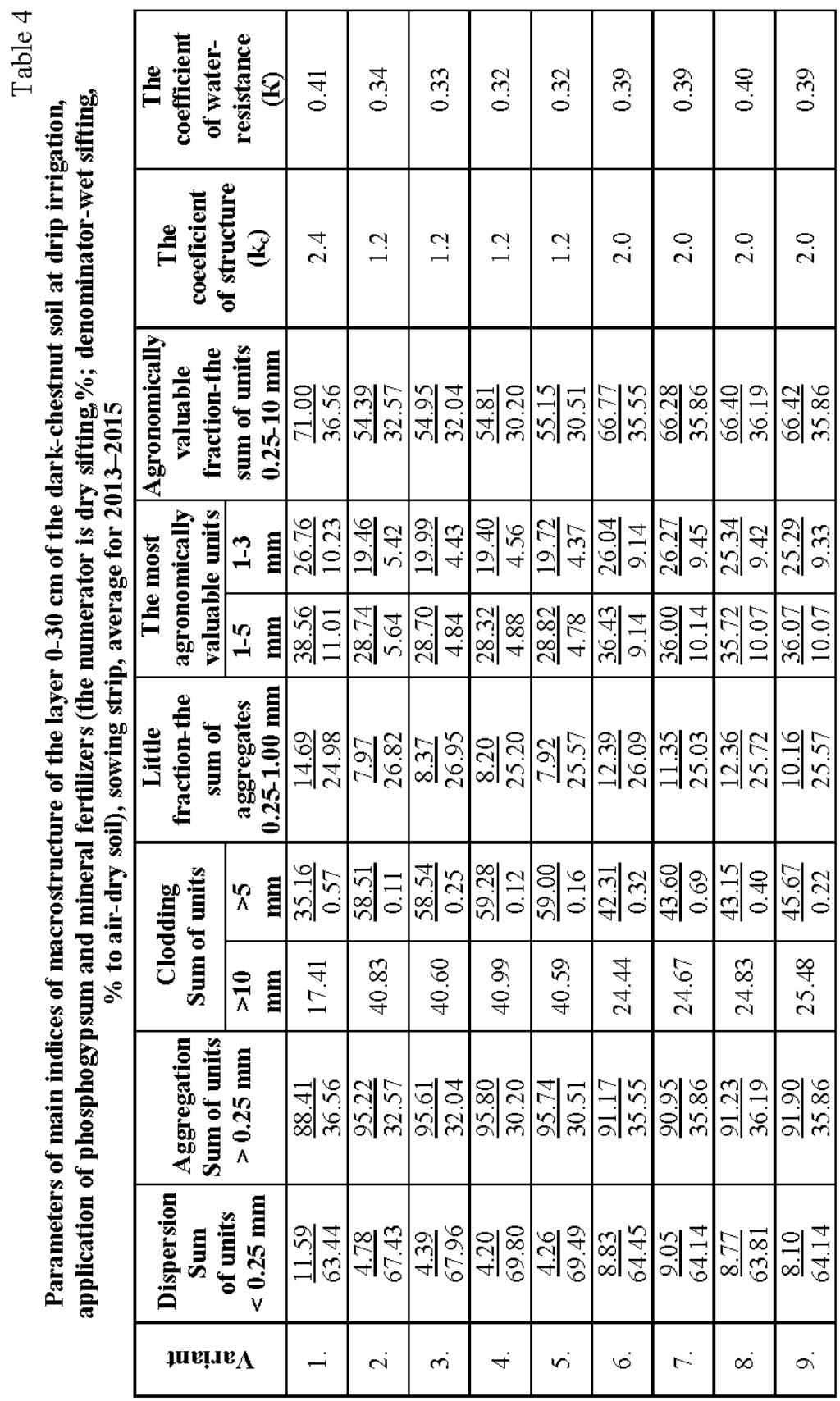




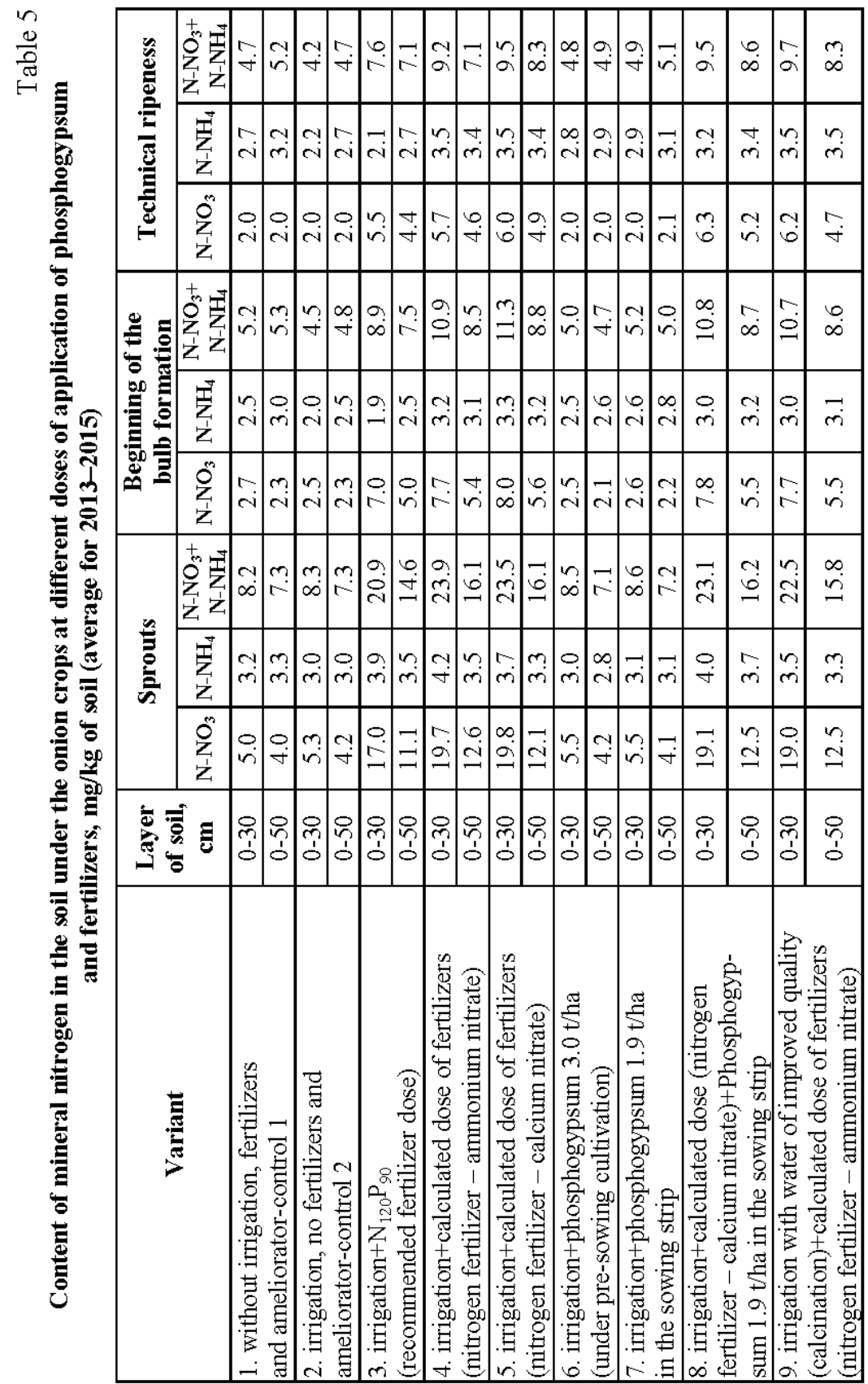


The use of phosphogypsum (under the pre-sowing cultivation, in the strip of sowing against the background of mineral fertilizers) and irrigation with the water of improved quality significantly slowed down the level of negative influence of mineralized waters on the soil structure. In this case, the content of the aggregates larger than $10 \mathrm{~mm}$ was within 24.44-24.83\%, which is by $7.03-7.42 \%$ more than on the control variant without irrigation, and by $16.39-16.00 \%$ less than in the soil layer of 0-30 $\mathrm{cm}$ with drip irrigation.

On the variants with the use of chemical reclamation of soil and irrigation water, the contents of dry sifted of agronomically valuable and the most agronomically valuable aggregates (the amount of fractions $1-5 \mathrm{~mm}$ ) was by $4.23-4.72 \%$ and by $2.80-2.13 \%$, respectively, lower than on the variant without irrigation. However, compared with the irrigated control, their number increased by $11.89-12.38 \%$ and $6.98-7.69 \%$, respectively.

The results of wet sifting of the soil testified that under the application of melioration measures, the main indicators of the waterresistant structure of the surface layer of the soil were preserved close to the control variant without irrigation: the content of water-resistant aggregates (the sum of the aggregates of more than $0.25 \mathrm{~mm}$ ) $-35.55-36.19 \%$, and the most agronomically valuable aggregates (the amount of the aggregates with the size of $1-3 \mathrm{~mm})-9.14-10.14$ at the amount on the control variant without irrigation of 36.56 and $10.23 \%$, respectively. The coefficients of structure and water resistance of $0-30 \mathrm{~cm}$ layer of the irrigated soil on the variants with the use of chemical reclamation were the same and close to the indicators on the control version without irrigation.

Assessment of the agro-physical state of $0-30 \mathrm{~cm}$ layer by the criteria of the degree of irrigated soil degradation allows us to conclude that the use of phosphogypsum (under pre-sowing cultivation in the dose of $3 \mathrm{t} / \mathrm{ha}$, in the sowing strip of $1.9 \mathrm{t} / \mathrm{ha}$, against the background of mineral fertilizers) and the use for irrigation of the water of improved quality (calcinated one) led to the development of irrigative soil degradation at the level of low degree by the content of air-dry aggregates with the size of $0.25-10 \mathrm{~mm}$, waterresistant aggregates of more than $0.25 \mathrm{~mm}$.

\section{Nutrition regime of the dark-chestnut soil under the crops of onion at the application of phosphogypsum and mineral fertilizers}

Modern approaches to the development of practical aspects of fertilizers use are associated with the assessment of nutrition conditions of soil. Spatial and timeline dynamics of nutrients, their transformation in the soil is one of the main factors that determine the condition of mineral nutrition, 
and, as a consequence, the effectiveness of fertilizers, yield and quality of products of crops, including onion ${ }^{7}$.

Ammonium nitrogen in the life of plants has much less value as nitrate. This is primarily due to the high nitrification ability of soils. According to the data of scientific literature ${ }^{8}$, even under the application of nitrogen fertilizers in the ammonium form after 8-12 days there is no more than $10-15 \%$ of ammonium nitrogen from the original quantity available in the soil. Therefore, the analysis of nitrogen soil regime, especially on the irrigated lands, is advisable to be carried out by the mineral nitrogen (the amount of nitrate and ammonium nitrogen).

The results of the study indicate that the amount of mineral nitrogen at the cultivation of onion from seeds in the drip-irrigated conditions in the soil layer $0-30 \mathrm{~cm}$ on the control variant without fertilizers was 8.2-8.3, and in the layer $0-50 \mathrm{~cm}-7.3 \mathrm{mg} / \mathrm{kg}$ of soil (Table 5). Application of mineral fertilizers has increased its content in 0-30 cm layer by 12.6-15.6 and in the layer $0-50 \mathrm{~cm}$ - by 7.3-8.9 $\mathrm{mg} / \mathrm{g}$ of soil, compared with the variant without fertilizers. The highest content of mineral nitrogen was found in the variants with application of the calculated doses of mineral fertilizers regardless on the form of nitrogen in them. We should note that the use of phosphogypsum as an ameliorator did nor significantly affect the amount of nitrogen in the soil.

At the stage of bulb formation the content of mineral nitrogen in the soil layer $0-30 \mathrm{~cm}$ decreased in all the variants of the experiment by 3.0-13.0; and in $0-50 \mathrm{~cm}-$ by $2.0-7.6 \mathrm{mg} / \mathrm{kg}$ of soil. Significant changes in the amount of mineral nitrogen took place mainly in the top 0-30 cm layer of the soil.

The analysis of the obtained results allows to assert that at the beginning of formation of bulbs the reduction of the content of mineral nitrogen in the soil on the control without irrigation (the layer of 0-30 cm) was $36.6 \%$ from the content at the beginning of the vegetation (stage of sprouting), whereas in the soil on the control with irrigation it was a little higher $-45.8 \%$.

Phosphogypsum application both under pre-sowing cultivation (3.0 t/ha), and in the sowing strip (1.9 t/ha) without the use of mineral fertilizers did not promote further increase in the intensity of nitrogen reduction compared to control with irrigation.

The highest loss of mineral nitrogen from the soil layer of 0-30 $\mathrm{cm}$ for the period sprouting- beginning of the formation of bulbs were observed on the variants with the application of mineral fertilizers $\left(\mathrm{N}_{120} \mathrm{P}_{90}\right.$, calculated dose

\footnotetext{
${ }^{7}$ Бритвич М.Д., Гончаренко В.Ю. Вплив добрив на врожайність цибулі залежно від сорту і норми висіву насіння. Овочівництво і баштанництво, вип. 31. К.: Урожай, 1986. С. 12-13.

${ }^{8}$ Приходько В.Е. Мелиоративное состояние, свойства и продуктивность орошаемых почв. Тези докладу ІІІ съезда почвоведов и агрохимиков Украинской ССР. Мелиорация и охрана почв. Х.: УНИИПА, 1990. С. 73-74.
} 
of fertilizers - nitrogen in the form of calcium and ammonium nitrate) 51.9-57.4\%.

As the study testified, at the end of the vegetation of the crop the content of mineral nitrogen decreased in the layer of $0-30 \mathrm{~cm}$ on the control variant with irrigation to 4.2 and in $0-50 \mathrm{~cm}-$ to $4.7 \mathrm{mg} / \mathrm{kg}$ of soil. On the variants with application of mineral fertilizers $\left(\mathrm{N}_{120} \mathrm{P}_{90}\right.$, calculated doses of fertilizers - (nitrogen in the form of calcium and ammonium nitrate) its remained content was higher (in the layer $0-30 \mathrm{~cm}$ by $3.5-6.4$, in the layer $0-50 \mathrm{~cm}$ - by $2.4-3.9 \mathrm{mg} / \mathrm{kg}$ of soil).

During this period, the mineral nitrogen at the application of phosphogypsum (3 t/ha under the pre-sowing cultivation, $1.9 \mathrm{t} / \mathrm{ha}$ in the sowing strip) was at the level of the control version with irrigation. It should be noted that the amount of mineral nitrogen in the layer of 30-50 cm almost unchanged during the vegetation of onion due to its intense use by the plants from the topsoil.

Reserves of mobile compounds of phosphorus relate to the basic indices of soil fertility. They depend on the soil granulometric composition, fertilization and agricultural activities ${ }^{9}$. The results of the study testified that the content of the mobile compounds of phosphorus in the soil dynamically changed during the vegetation of onion. The maximum amount of available phosphorus was observed in the stage of the onions sprouting. In the arable layer of the control variant (without irrigation, irrigation without fertilizer) the content of mobile phosphorus was $73.3-73.4 \mathrm{mg} / \mathrm{kg}$ of soil. Application of nitrogen fertilizers (calculated dose of fertilizers - nitrogen in the form of calcium and ammonium nitrate) and phosphogypsum significantly affected its quantity in the soil. Application of the recommended dose of mineral fertilizers $\left(\mathrm{N}_{120} \mathrm{P}_{90}\right)$ increased the content of mobile phosphorus by $13.6 \mathrm{mg} / \mathrm{kg}$ of soil compared with the irrigated control.

In the subsequent stages of the onion development, the reduction in the content of mobile phosphorus in the soil on all the variants of the experiment has been developed. The smallest amount in the soil was observed at the stage of technical ripeness of onion.

On the control variant without irrigation the content of mobile phosphorus in the soil compared to the beginning of vegetation of onion reduced by $28.3 \%$, and in the variants with application of mineral fertilizers and phosphogypsum - by 33.6-42.6\%.

It should be noted that in the period "beginning of bulbs formation technical ripeness" on the variants with the increase of intensity of mobile phosphorus in the soil was almost 2 times higher than in the period of

9 Киселев В.Д., Кривоносова Г.М. Агрохимическая характеристика черноземов и каштановых почв. Агрохимическая характеристика почв СССР. М.: Наука, 1973. С. 227-246. 
"sprouts - beginning of bulbs formation". This phenomenon can be explained by the fact that at this time the plants used this nutritive element more intense.

It is known that the chestnut soil has relatively high reserves of potassium, so the dynamics of its exchangeable form under the crops had weak manifestations. In the irrigated conditions changes in the content of exchangeable potassium in the soil are mainly due to the use of it by the plants and transformation of its non-exchangeable form into exchangeable.

The study helped to find that high content of exchangeable potassium $358.0-376.0 \mathrm{mg} / \mathrm{kg}$ of soil was observed at the beginning of the crop vegetation in the $0-30 \mathrm{~cm}$ soil layer at the start of the onions growing (germination). In the process of the plant development, its number decreased in the soil on all the variants of the experiment. The smallest amount of exchangeable potassium in the soil is fixed in the technical ripeness stage of onions. It should be noted that in this stage its amount reduced in comparison to the stage of sprouting by $13.7-15.1 \%$.

Analyzing the dynamics of potassium content in the soil, it was established that in the period of "sprouts - the beginning of bulbs formation" the reduction of the content of exchangeable potassium due to the uptake by the plants was 3.4-6.4\% in comparison to the beginning of the crop growth, and for the period "the beginning of bulbs formation - technical ripeness" it was 1.4-2.9 times higher. Therefore, the maximum amount of potassium was used by onion in the second half of the vegetation period.

\section{CONCLUSIONS}

1. Drip irrigation with low mineralized waters of the second class led to the increase in the zone of "humidification" both of total amount of salts and toxic ones. In this case, the transformation of the salts' composition was due to the reduction of calcium salts in the soil layer of $0-30 \mathrm{~cm}$ by $8.3 \%$ and the increase in sodium salts by $7.6 \%$ of the total amount.

2. The application of phosphogypsum and irrigation with the water of improved quality contributed to the increase in the ratio of water-soluble calcium to sodium in the sowing strip (soil layer $0-30 \mathrm{~cm}$ ) by $0.5-0.8$ units that ensured the transition of the active degree of salinity into passive.

3. Irrigation with the water of improved quality and application of the calculated dose of mineral fertilizers with the use of calcium nitrate against the background of phosphogypsum in the sowing strip ensured the stabilization of the content of monovalent cations $\left(\mathrm{Na}^{+}+\mathrm{K}^{+}\right)$at the level of the control variant without irrigation $-3.8-4.0 \%$ against $3.7 \%$, respectively (soil layer $0-30 \mathrm{~cm}$ ).

4. In the arable layer of soil $(0-30 \mathrm{~cm})$ on the chemically ameliorated variants there was a tendency to the improvement of the structure compared to the control with irrigation, which was confirmed by a greater number of agronomic aggregates and higher coefficient of structure. 
5. Application of mineral fertilizers provided the increase in the content of nutrients for the plants of onion throughout the vegetation. The highest expenditures of mineral nitrogen $\left(\mathrm{N}-\mathrm{NO}_{3}+\mathrm{N}-\mathrm{NH}_{4}\right)$ in the soil layer $0-30 \mathrm{~cm}$ were observed on the variants with application of fertilizers $\left(\mathrm{N}_{120} \mathrm{P}_{90}\right.$, calculated doses of fertilizers - nitrogen in the form of calcium and ammonium nitrate) during the period of "sprouts - the formation of bulbs" - 51.9-57.4\% of the initial quantity. The intensity of reduction in the content of mobile phosphorus in the soil on the irrigated variants during the "beginning of bulbs formation technical ripeness" was 2 times higher than in the period of "sprouts-the beginning of bulbs formation". The largest amount of exchangeable potassium used by onion was in the second half of the vegetation period.

\section{SUMMARY}

The article presents the results of the study on the impact of drip irrigation with low mineralized waters with adverse ratios of mono- and divalent cations, and methods of phosphogypsum application (scattering of $3 \mathrm{t} / \mathrm{ha}, 1.9 \mathrm{t} / \mathrm{ha}$ in the strip of sowing and calcination of irrigation water) on the agro-meliorative state of soil, taking into account the chemical, physical, physico-chemical properties of dark-chestnut slightly saline soil. The nature and direction of changes in its properties under various ways of the use of ameliorator improved onion's productivity. It was established that phosphogypsum fertilization contributes to the stabilization of secondary salinity at the level of the slight degree.

The method of chemical reclamation with the use of mineral fertilizers (calcium nitrate) and phosphogypsum (in the sowing strip) is offered, which ensures the preservation of agro-meliorative state of the dark-chestnut soil.

\section{REFERENCES}

1. Землі Інгулецької зрошувальної системи: стан та ефективне використання. За наук. ред. В.О. Ушкаренко, Р.А. Вожегової. К.: Аграрна наука, 2010. 352 с.

2. Кукоба П.І., Балюк С.А., Ладных В.Я. Повышение плодородия мелиоративного фонда. Почвы Украины и повышение их плодородия, т. 2. К.: Урожай, 1988. С. 92-103.

3. Рабочев И.С. Использование минерализованных вод для орошения и рассоления почв, основное направления дальнейших исследований. М.: Колос, 1973. С. 6-25.

4. Остапов В.И., Сафонова Е.П. Влияние орошения на плодородие почв степной зоны Украины. Гидротехника и мелиоращия, № 5. 1986. C. 54-57.

5. Дорогунцов С.I., Муховиков А.М. Оптимізація природокористування. Природні ресурси: еколого-економічна оцінка. К.: Кондор, 2004. T. $1.291 \mathrm{c}$. 
6. Гедройц К.К. Избранные сочинения, т. 1. М., 1955. 560 с.

7. Гринченко О.М. Улучшение солонцов и солонцеватых черноземов способом химической мелиорации. Записки ХСХИ; вып. 1-2, т. 2. X., 1939. C. 48-56.

8. Порядок оцінки солонцюватості грунтів у зонах впливу зрошувальних систем. Посібник до ВНД 33-5.5-11-02 «Інструкиія з проведення трунтово-сольової зйомки на зрошуваних землях Украӥни». К., 2002. 20 с.

9. Ромащенко M.I. Зрошення земель в Україні. Стан та шляхи поліпшення. К.: «Світанок», 2000. 114 с.

10.Бритвич М.Д., Гончаренко В.Ю. Вплив добрив на врожайність цибулі залежно від сорту і норми висіву насіння. Овочівництво $i$ баштанництво, вип. 31. К.: Урожай, 1986. С. 12-13.

11. Приходько В.Е. Мелиоративное состояние, свойства и продуктивность орошаемых почв. Тези докладу III съезда почвоведов и агрохимиков Украинской ССР. Мелиорачия и охрана почв. Х.: УНИИПА, 1990. C. 73-74.

12. Киселев В.Д., Кривоносова Г.М. Агрохимическая характеристика черноземов и каштановых почв. Агрохимическая характеристика почв СССР. М.: Наука, 1973. С. 227-246.

Information about the author: Shkoda O. A., Candidate of Agricultural Sciences, Head of the Laboratory of Analytical Studies, Institute of Irrigated Agriculture of the National Academy of Agrarian Sciences of Ukraine Kherson, Naddnipryanske, 73483, Ukraine 